\title{
Preface to the Paperback Edition: A Scholarly Update
}

This is essentially the same book as the original edition. In order to minimize production costs, I have resisted the temptation to correct anything but the most obvious omissions and typographical errors. Moreover, since completing the book I have been working on other projects, and so I am not in a position to substantially update the contents. Nonetheless, I would like to use this introduction to modify a few details and introduce new Japanese research on Michizane and Tenjin worship (parenthetical page references all indicate relevant sections of my book).

If forced to pin down a scholarly trend, I would submit that, since I completed my original research, the major new development has been a growth of interest in Japan's literature in Chinese, including Michizane's works. In recent years, two of the major Japanese journals of literary scholarship have published special numbers, one focusing on "The World of Heian Court Literature in Chinese"'1 and the other on "Poetic Thought, Poetic Criticism: Sugawara no Michizane and $\mathrm{Ki}$ no Tsurayuki.",2

1 Kokubungaku: kaishaku to kansho 55.10 (Oct. 1990).

2 Kokubungaku: kaishaku to kyözai no kenkya 37.12 (Oct. 1992). 
Each includes a review of scholarship concerning Michizane by a leading specialist. The first, by Fujiwara Katsumi (whose first studies of Michizane's poetry were appearing as I was completing my research), is the most comprehensive; the second, by Kimbara Tadashi (whose surname appeared as "Kimpara" in earlier publications, including my own), acknowledges Fujiwara's essay and builds on it. These two surveys and the various other articles that appear in the same special numbers of the journals offer a comprehensive overview of the current state of relevant Japanese scholarship, and most of it is literary. In contrast, the standard guides to historical research reveal many items that might help us understand Michizane's age, but nothing focusing on the man himself. Readers unfamiliar with Michizane and the Heian period may want to read at least the introduction to my book before proceeding with the rest of this preface so they will have some sense of what it is updating.

Literary studies treat both Michizane's literary thought and practice. For some years Japanese scholars have been interested in early Heian theories of literature, which are introduced in my book (pp. 17-20 and 39-48 in particular). Attempts by some, however, at explaining Heian academic factionalism in terms of ideological disputes between poets (shijin) and scholars (ju) seemed misguided, since Michizane clearly identified himself as both, in keeping with Confucian teachings (pp. 84-85). The surveys of literary scholarship reveal that Michizane's self-identity as a poet and attitude toward other scholars remain central issues among Japanese specialists, whose research has added increasing sophistication to the discussion. Reading some of their arguments and reviewing what Michizane himself had to say have led me to believe that perhaps I was too hasty in dismissing the question.

To start with Michizane's own writings, Kawaguchi and Wakabayashi's concordance of his poetry confirms that, in his usage, intellectuals fell into two categories and he included himself in only one of them. The character $j u$ that I translated as "scholar" or sometimes "Confucian scholar" - scholars were by definition Confucian-appears a total of seventeen times in Michizane's poetry (for example, pp. 123, 133, 139, 157, 172, 299). The character is used in various compounds but refers to Michizane himself in all but three instances. In these exceptions, it appears in compounds-kōju or $t s \bar{j} j u$ - both meaning something 
like "erudite scholar." A partial explanation of this distinction would be that "erudite scholar" is an honorific usage necessarily reserved for those other than oneself. Emperor Uda politely referred to Michizane as an erudite scholar (p. 214), whereas Michizane occasionally described himself as a "worthless (literally, 'rotten') scholar" (fuju). When Michizane wrote of "erudite scholars," however, he seemed to be using the term ironically rather than honorifically, and so at one point I translated kojju as "lofty Confucian scholar" (pp. 84-85) to convey something of the tone that I believe he intended. For example, in a poem mourning the death of a man he praised as a true poet, he uses that term disdainfully to describe other intellectuals who were not. ${ }^{3}$

The concordance reveals that Michizane used the word "poet" nine times, "poetic friend" (shiyū) three, and "poetic minister" (shishin) twice (the only two examples I translated are on pp. 178, 181). He uses these terms to refer sometimes to himself, sometimes to others, and sometimes to poets in general. Never does he use them ironically. Poets, unlike scholars, are always viewed positively, and he specifically notes that the poet whose death he mourned was neither a close friend nor a student of his. Still, according to Michizane, after his death, only two or three men at court could be regarded as true poets. Thus apparently factionalism was not Michizane's only criterion in classifying scholars. All, including himself, fell under the broad rubric of $j u$, but only a few, again including himself, were worthy of the name poet. Since at least one whom he praised as a poet did not belong to his own clique, perhaps we should acknowledge that the reverse could also be true: those whom he disparaged may not have been simply members of rival factions.

Fujiwara Katsumi has written a series of articles on this issue that hint at the substantive differences between the two groups of scholars and substantially illuminate what being a poet meant to Michizane. ${ }^{4}$ He takes the Ako Incident (pp. 169-181) as a key to understanding the intellectual climate of Michizane's day. Scholars had been summoned to determine whether the elegant

\footnotetext{
$3 K B K K$, item 502.

4 The material that follows is based largely on his most recent piece, "Michizane: shi to shiso,"' Kokubungaku kaishaku to kyozai no kenkya 37.12 (Oct. 1992): 46-52. His previous research is summarized in the two survey articles noted above that also note other publications on this topic.
} 
sinified title "akō," used in the document appointing a new chancellor, referred to a post that was merely honorary and hence was meant as a discreet means of removing him from power. Fujiwara notes that the professors of classics indeed looked only to the orthodox Confucian classics for precedents whereas scholars associated with the court university's literature program, including Michizane, referred to later historical works as well. Since history was regarded as a branch of literature, this hints at real differences in the intellectual approaches of the two groups.

Fujiwara further observes that Michizane never referred to literature as a force in the ordering of the state, the slogan of his grandfather's day that had been borrowed from a Chinese source (p. 43). Instead, Michizane alluded to another familiar Chinese justification of poetry that originated in the Great Preface to the Book of Songs, which states "Poetry is where one's intention goes: that which is in the heart becomes poetry when expressed in words." Although this is a view of poetry that has been classified as "expressive," the same source goes on to explain that people's feelings will mirror the quality of their rulers and one of the functions of poetry is to allow inferiors to subtly remonstrate their superiors. Hence, it merges with the concept of "literature as a force for ordering the state" in also upholding the familiar Confucian pragmatic theory of literature. ${ }^{5}$

According to Fujiwara, this view of poetry that combines expressive and pragmatic elements lay at the core of Michizane's poetic practice. It justified his composing poems extolling the beauties of nature and, at the same time, encouraged him to seek a moral basis for such poetry. More concretely, it gave Michizane the moral courage to risk incurring the chancellor's displeasure by protesting his behavior in the Akō Incident as detrimental to literature, for Michizane regarded literature as a high calling based on the expression of "intentions," including political

5 James J. Y. Liu, Chinese Theories of Literature, pp. 69-70, 11-13. In ancient China, the words for "poetry" and "intention" may have been in fact the same (see Chow Tse-Tsung, "The Early History of the Word Shih [poetry]," Wen-lin: Studies in Chinese Humanities, ed. Chow Tse-tsung [Madison: University of Wisconsin Press, 1968] pp. 151-209). Both the Chinese original and an English translation of the passage from The Book of Songs to which Michizane alludes can be found in The She King, trans. James Legge, in The Chinese Classics, vol. 4 (originally published in 1871 and reprinted many times), pp. 34-36. 
views. This attitude also led him to disparage the less courageous scholarly sycophants to whom he applied the two terms for "erudite scholar" noted above. Although we still lack a clear picture of what those who opposed Michizane's ideas actually believed, Fujiwara and others who have been working on this question have contributed much to our understanding of Michizane's own literary attitude.

Research on Michizane's poetic practice tends to seek distinctive elements in his work and show how it differed from his Chinese models. For example, a Chinese scholar has noted that his use of certain adverbs deviates from normal Chinese grammar. Thus Michizane seems to have been thinking of the Japanese verb suffix that indicates the passive voice when he used the adverbial character that serves a similar function in Chinese. Similarly, another specialist has discovered in Michizane's poetry the earliest known example of using the now-standard character to write the Japanese word "niou," meaning "to be fragrant," or "to be colorful." According to this authority, in Chinese the character meant "resonance" or "to arrange." Standard dictionaries, however, indicate that the character Michizane used is in fact a Japanese original derived from the character that means "resonance." Could Michizane have invented it? Another scholar has investigated Michizane's descriptions of chrysanthemums, showing how he adopted Chinese metaphors and conventions. Still others have pointed out that he employed legal jargon from the ritsuryō codes, particularly in poems he wrote while serving as a provincial governor. As governor, apparently he became so involved in practical administrative problems that their technical vocabulary crept into his poetry, another deviation from Chinese literary models. Also, the question of Michizane's authorship of Shinsen Man'yōshū is still being debated among scholars. Regardless of who wrote it, it is a fascinating work that deserves more attention as a guide to understanding the relation between poetry in Chinese and in Japanese.

Continuing along these lines but in bolder strokes, the contemporary poet Ooka Makoto has written a book on Michizane that puts his work in the context of a perceived fundamental pattern in Japanese culture: borrowing elements of foreign cultures and attempting to further refine them. He treats Michi- 
zane as an example, a "modernist" who confronted problems similar to those facing contemporary Japan. ${ }^{6}$ Fujiwara too finds something very Japanese in Michizane's work. His analysis of Michizane's concept of poetry closes with the observation that it resembles the view of Japanese poetry presented in the introduction to the Kokinshū shortly after Michizane's death. Fujiwara concludes his review of scholarship on a similar note by suggesting, as others have before, that even if the motto "Japanese spirit, Chinese learning'" may have been attributed to Michizane falsely (p. 4), it does accurately reflect his attitude. This is a somewhat different emphasis from the perspective I brought to Michizane. I chose to study him in part as an attempt to put a positive light on elements of Chinese culture in the early Japanese court, and so I portrayed a Michizane who wears his Chinese garb comfortably. Perhaps the Japanese views of Michizane may reflect an inclination to turn to exemplars from the past when seeking to confirm contemporary self-identity.

One expression of Michizane's assimilation of Chinese culture was his ability to compose poems in Chinese extemporaneously. I would like to correct an error that appears in my discussion of such poems. I state that he did not take time to "add punctuation'" (pp. 97-98, 143, 236). This is a mistranslation. The character I rendered as "punctuation" does mean that (as a noun), but (as a verb) it can also mean "to make small corrections," and the phrase Michizane used is a standard one meaning simply "to revise a manuscript." When Michizane tells us he composed a poem without revision, we learn that even his extemporaneous poems are quite good, but we can not judge whether or not he was able to read them directly in Chinese without rearranging them into Japanese word order, as I had suggested. I still believe this to be a strong possibility, but I have lost one piece of supporting evidence.

Although I have focused on Japanese contributions to our understanding of Michizane's writings, I would also like to call attention to two studies in English. Helen McCullough's Brocade by Night: 'Kokin wakashü' and the Court Style in Japanese Classical Poetry, which came out after my book had gone to press, discusses Michizane's poetry, Shinsen Man'yōshū, early Japanese literary

- Shijin Sugawara no Michizane: utsushi no bigaku (Tokyo: Iwanami Shoten, 1989). 
theories, and other topics related to my own study. ${ }^{7}$ David Pollack's provocative The Fracture of Meaning: Japan's Synthesis of China from the Eighth through the Eighteenth Centuries incorporates and expands on his article mentioned in my bibliography. ${ }^{8}$

Moving from literary to historical issues, I would like to update my discussion of kentōshi, Japan's missions to T'ang China. Charlotte von Verschuer has published a meticulously detailed study that provides a wealth of information on the conduct of these missions. Among other important contributions to our understanding of these missions in general, she notes that they typically departed Japan when the weather was most favorable. ${ }^{9}$ This contradicts the traditional view, adopted uncritically in my book (p. 34), that the early Japanese were unaware of the regular monsoon winds and sailed at the worst possible time, an interpretation that apparently originated with Mori Katsumi and was repeated by Edwin Reischauer. ${ }^{10}$ The most detailed critique of Mori is presented by Ueda Takeshi. ${ }^{11} \mathrm{He}$ concludes that most of the missions left Kyushu between late July and late August (by the Western calendar), just after the rainy season when favorable winds were likely to be blowing. This was the best possible time of the year, as long as typhoons could be avoided. Although typhoons were unpredictable and did occasionally wreak havoc, this does not mean that Japanese sailors were ignorant of normal weather patterns.

My treatment of the abandonment of the kentöshi (pp. 240-250) also needs modification. In a tour de force of textual scholarship, Ishii Masatoshi has written an article that clears up one mystery principally by analyzing the usage of a single commonplace character. ${ }^{12}$ Scholars have long been puzzled by the apparent speed of the Heian court in accepting Michizane's proposal that his mission to China be canceled. Ishii calls into question the reliability of the only source, Nihon kiryaku, that places this

7 Stanford: Stanford University Press, 1985.

8 Princeton: Princeton University Press, 1986.

- Les Relations Officielles du Japon avec la Chine au VIIIe et IX siecles (Geneva: Librairie Droz, 1985), p. 56.

10 See, respectively, Kentoshi, pp. 55-60 and Ennin's Travels, pp. 60-61.

11 "Kentoshi, Shiragishi, Bokkaishi no rekishi kikogakuteki kenkyu: kodai kaijō kőtsũ to kisetsufo to no kankei," Hosei tsushin (Aug. 1974): 16-28.

12 “'Iwayuru kentoshi haishi ni tsuite: Nihon kiryaku teishi kiji no kento,," Chūo Daigaku bungakubu kiyo shigakka 35 (Feb. 1992): 1-21. 
decision just sixteen days after Michizane's proposal (p. 243). Ishii shows that it commonly confused two characters, similar in appearance, one meaning "this" and the other meaning "a certain." When the compiler introduced an event but knew only its month, not its exact date, he included it in the entry for the last day of the month and introduced it with the phrase "on a certain day," presumably of that month. The problem is that he, or a later copyist, often substituted the graphically similar character, changing the phrase to "on this day" and giving the entry a false appearance of precision. Furthermore, Ishii notes that the wording in this brief entry employs language also found in Michizane's proposal.

Ishii concludes that the court never made a formal decision to cancel Michizane's mission to China. Rather, as a result of Michizane's proposal, dispatch of the mission was first put off, and, without any formal decision, interest in it waned and eventually vanished. The compiler of Nihon kiryaku knew that the mission was never sent, but he had neither a record of the decision nor a precise date. Accordingly he improvised, placing a vague entry at the end of the month in which Michizane made his proposal. In a footnote, Ishii also dismisses as a later fabrication the source I quote stating that an edict canceling the mission was issued the year after Michizane's proposal. Its author, Ishii asserts, further garbled an already unreliable account in Fusō ryakki describing the arrival that year of envoys from the Manchurian kingdom of Parhae (pp. 250-252) and managed to confuse their appearance in Japan with the cancellation of Michizane's mission.

If Ishii is right, and I suspect he is, some modification of my argument is in order, although his conclusions are in keeping with the general outline of my treatment of the problem. My suggestion that, as late as 927 , the Japanese had not precluded the possibility of sending further embassies to China seems more reasonable if we assume that the court never even formally canceled Michizane's embassy, much less decided to cut its diplomatic ties with China altogether. On the other hand, further doubts must be added to my suggestion, tentative from the start, that the source with a later date for the abandonment of Michizane's mission may be the more reliable one. Ishii seems to have solved the mystery of the all-too-prompt official response to Michizane's 
proposal, but I believe that otherwise my discussion of the circumstances surrounding Michizane's appointment and the failure to dispatch his mission to China remains valid, even if we now must suspect that no decision was formally made.

Finally, Tenjin, Michizane's deified spirit, has also received considerable scholarly attention in the form of at least six substantial books and numerous articles. Together, they offer fresh insights into many aspects of Tenjin worship. Most of the items, however, are rather narrow in focus, and a comprehensive overview of the subject is still needed. Perhaps a brief survey of some key publications will help explain why scholars still focus on details.

Three of the books are in fact collections of articles. Makabe Toshinobu's Tenjin shinkō no kisoteki kenkyū brings together his previously published articles-many already cited in my bibliography - updates them, adds a couple of new essays, and rounds out the collection with good editions of two early accounts of Michizane's life. ${ }^{13}$ As careful readers of my footnotes will notice, Makabe is the leading authority on early biographies of Michizane and sources for the Tenjin legend, and his research on these texts clarifies how Tenjin worship evolved. Previously published essays by various scholars have been collected by Murayama Shūichi in Tenjin shinkō. ${ }^{14}$ These articles, the oldest dating back to 1914, are central to our understanding of Tenjin worship, and again many appear in my bibliography. Murayama contributes a critical review of scholarship on Tenjin worship that reveals something of the subject's complexity, discussing fascinating topics that I omitted from my book. For example, the fear of angry ghosts that led to Michizane's deification had ties not only to popular Buddhism (p. 310) but also to other cults that may have originated in China and involved animal sacrifices. The third collection of articles, Temman Tenjin: goryo kara gakumon no kami e, edited by Ueda Masaaki, consists of new articles written by distinguished authorities for general readers. ${ }^{15}$ Most of the authors treat material they have presented elsewhere in more technical articles. Others, however, cover

\footnotetext{
13 Kondo Shuppansha, 1984.

14 Yazankaku, 1983.

15 Chikuma Shobo, 1988.
} 


\section{$x x i i \cdot$ Preface}

less familiar topics. One that I found particularly intriguing introduces various daily records that were kept at Kitano Shrine in Kyoto from 1449 to 1688 and briefly describes their contents. In addition to the spread of Tenjin worship, we read about shōen, shoguns, and peasant uprisings: topics familiar to readers of most books about medieval Japanese history that are lacking in my own study, even when the concluding chapter does venture into the period. A fourth book is Stanca Scholz's Aspekte des Mittelalterlichen Synkrestismus im Bild des Tenman Tenjin im Nō, which discusses noh plays, some familiar, others obscure, based on the Tenjin legend. ${ }^{16}$ It includes, for example, a translation into German of a noh play, Kinzanji, not even available in a modern Japanese edition, that is based on the legend of Michizane's posthumous journey to China (p. 327).

The two remaining books are collections of documents. One, Dazaifu, edited by Nakano Hatayoshi, appears in the series Shintō taikei. ${ }^{17}$ Whereas the previously published volume in that series on Kitano shrine included many familiar texts that are key to the history of Tenjin worship, the documents in this volume are more diverse. They are divided into five groups: histories of the Dazaifu shrine, descriptions of shrine rituals, records of its construction, documents concerning its economic foundations, and genealogical accounts of its head priests. A second valuable collection of documents is Tenjin densetsu no subete to sono shinko,, compiled by Yamanaka Kosaku. ${ }^{18}$ It includes 966 variations of 118 basic stories concerning Tenjin, plus the first modern edition of a detailed recounting of the Tenjin legend dating from the Edo period. Some of the stories such as the plum tree that flew to Kyushu are familiar (pp. 290-295). Others are not: "Once upon a time, Tenjin was chased by a white dog and fled into a field where he slipped on a taro plant, poked his eye on a sesame leaf, and fell into a well. Afterwards, it is said, they did not keep white dogs, raise taro and sesame, or dig wells there."

As this summary, incomplete though it is, demonstrates, Tenjin worship is a diffuse phenomenon. Its history is all-too-

16 Stuttgart: Franz Steiner Verlag, 1991.

17 Jinja hen, vol. 48 (Shintơ Taikei Hensankai, 1991).

10 Dazaifu: Dazaifu Temmang Bunka Kenkyajo, 1992. 
well documented and can be approached from many directions. This very complexity of the subject discourages scholars from attempting to write a comprehensive survey.

The items mentioned so far point to a need to expand rather than correct my treatment of Tenjin worship. A series of articles by Takei Akio, however, suggests that my treatment of the Doken legend (pp. 315-319) may need revision. ${ }^{19}$ Two early versions of the story survive, and Makabe believes that at least the longer text was probably written not long after the events presumably took place in 941 but acknowledges that the dating is problematic. Takei on the other hand argues that the longer version, which shows more influence of esoteric Buddhism and includes the story of Dōken's visit to hell, may date from

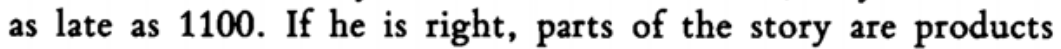
of the growing popularity of Tenjin worship rather than contributions to it. Finally, at the risk of seeming immodest, I would like to mention an article I have written, "Sugawara Denju: Life, Religion, and Drama," that analyzes the biographical, legendary, and theatrical elements that went into the making of the ever-popular play The Sugawara Secrets of Calligraphy. ${ }^{20}$

I hope this preface, in addition to updating and correcting my own book, will suggest new areas for future research. Also, I would like to thank my colleague Professor Marian Ury for sharing with me her list of details needing correction and Patricia Crosby of the University of Hawaii Press for facilitating the publication of this paperback edition of my book.

\footnotetext{
19 "Nichizoden tenkai no issokumen: toku ni Shingon mikkyő to no kanren ni tsuite," "Nichizo meikai henrekitan oboegaki," and "Eikyũjibon 'Doken shơnin meidoki' ni kansuru ni san no mondai," all appearing in Kodai bunka 28.3 (March 1976), pp. 57-69; 29.6 (June 1977), pp. 42-49; and 39.1 (Jan. 1987), pp. 24-37, respectively.

${ }^{20}$ In Literary Relations East and West, ed. Jean Toyama and Nobuko Ochner (Honolulu: University of Hawaii Press, 1990), pp. 166-173.
} 
